\title{
Toward a Critical Stance: Citizenship Education in the Classroom
}

\author{
Diane M. Vetter \\ York University
}

\begin{abstract}
In this paper the author presents the argument that through the use of rich classroom talk, students can be motivated to take a critical stance on issues of citizenship, such as social justice, equity and environmental concern. Suggesting that students who are not part of the solution are, indeed, part of the problem, the author advocates giving young children a voice through the integration of citizenship education and critical literacy across the curriculum to promote student awareness and to empower students to become pro-active global citizens.
\end{abstract}

As a teacher with a keen interest in issues of equity and social justice, I struggle to make apparent to my students the issues of global citizenship that rarely impact their lives in a small Ontario town — knowing that many of these issues have a huge impact on my teaching colleagues and their students in larger urban centres.

This discussion looks at the value of classroom talk as a means of empowering students to global awareness and examines what empowerment of students toward a critical stance that facilitates the education of global citizens might look like in the primary or junior classroom.

\section{The Roots of My Enquiry}

The basis of my work is the exploration of a powerful lesson that my students taught me. The lesson was the result of an unexpected finding during my Masters' thesis research, which demonstrated significant empowerment of the children in my study toward a critical stance, through the implementation of oral communication teaching methodologies. While there have been numerous subsequent examples in my teaching and research work that have supported these initial learnings, it is the following lesson that was the catalyst for this discussion.

Diane Vetter is a teacher with the Simcoe Muskoka Catholic District School Board and is a Ph.D. candidate at York University. She is currently seconded to the York University Faculty of Education Pre-Service programme. She can be reached at diane_vetter@edu.yorku.ca 
During a six-month research period, I studied the oral interactions of students in a Grade 1 classroom. Throughout the six months, we did a great deal of reading and talking about important issues that affect our world such as environmental concerns and social justice - at a primary level. At the end of the school year, our class was invited to perform a song for the parent volunteer appreciation tea. We chose to sing One Small Voice (Moss, 1989). After our song, the principal congratulated the students on their performance and asked them to share with the parents what they had learned in grade one. The first few students provided the expected responses - I learned to read - I learned to do "pluses" - I learned to write; however, the next student stunned the parents, and me, when he proudly declared, "I learned that I can make the world a better place." His classmates nodded their heads in agreement.

The intent of my research in the grade one classroom had been to allow students the opportunity to engage in rich talk (Vetter, 2003), by providing them with the opportunity to learn through engagement with peers, teachers, and classroom guests. In our classroom, we made our voices heard through discussion, debate, and information sharing. To do so, we hosted a Canadian peacekeeper, worked on an eco-garden outside our window, and made critical connections to the world by reading powerful, illustrated texts that told stories of our environment and our world. However, as my research demonstrated, giving these young students a voice in the classroom led to their empowerment - to the belief that they could, indeed, make the world a better place.

Based on my research findings, I theorize that if children are provided with the opportunity to engage critically with issues of social justice, equity, and diversity that exist in the world around them, and, importantly, are shown that their voices are valued and respected, they will develop the ability to discern injustice and the confidence to speak out about social justice issues. In doing so, they will be building a foundation of global awareness, from which they may begin the process of becoming pro-active global citizens.

\section{Why Empowerment of Students is Important}

Darling-Hammond (2002) remarks on the frustrations of pre-service teachers in her class who were attempting to engage fellow students in discussions around issues of "equity, marginalization, discrimination, and oppression" (p. 2) only to find that the majority of their classmates who had been raised within mainstream society were unaware of the issues.

Ten years from now, the students to whom I have referred in the preceding paragraphs may be graduating as teachers themselves. I suggest that today is not too soon to be raising their awareness of citizenship issues such as equity and social justice in society. Teachers have the opportunity to 
empower children to change the inequitable or quietly discriminatory practices that underlie student interactions and societal norms. I theorize that empowering all students to think critically and act justly today will work to create dialogue and action in the teachers, and indeed the citizens, of tomorrow.

Upon reading Darling-Hammond's (2002) remarks, my first reaction was to wonder how the pre-service teachers she refers to could be so naïve about the issues. Certainly, there is plenty of newspaper coverage about equity issues in society. Considering this question led me to some noteworthy Canadian statistics.

The Community Profile statistics from Statistics Canada (2005) demonstrate that, at the time of the last census, almost half of the people living in and around Toronto identify themselves as belonging to a visible minority. However, outside of the Toronto area only one-tenth of Ontarians self-identify as belonging to a visible minority group. The percentage of visible minority students in the small-town Ontario school where I conducted research for my Master of Education thesis was less than 1\%. These simple statistics tell me that outside of Toronto, many Ontarians may not be faced with daily issues of equity, discrimination, and marginalization based on race or ethnicity; therefore, the question arises as to what motivation teachers in these communities have to undertake multicultural initiatives, move toward a socially-just, anti-bias curriculum, and empower students to examine the role of marginalizing power within our society and globally. Although issues of discrimination and equity may be highly publicized in the news, removed from the reality, it is easy to say, It's not my problem.

As an example of the previous point, allow me to relate my experience taking a Grade 5 class to Toronto to visit the Legislative Assembly and the Royal Ontario Museum (ROM). After our visit to the Legislative Assembly, we enjoyed lunch in Queen's Park before walking to the ROM. As we made our way up Queen's Park, one of the students hollered to me from the back of the line, "How come there're so many Chinese people in Toronto?" My immediate reaction was to cringe at this loud question on a sidewalk that was, indeed, crowded with many Asian faces, and I quickly replied that he should save his questions for the classroom. However, looking at his sincere face, I realized that his question was valid and his choice of language and location were not intended to be disrespectful or racist. In that moment, that student taught me a valuable lesson about what I had neglected to teach in my classroom. How could I expect the students from our relatively homogenous school community to be sensitive to issues of diversity if I had never explicitly taught them about multiculturalism in Canada? How could I expect these children to know that Asian faces reflect a diversity of nations and cultures 
D. Vetter

that are a part of our Canadian multicultural society if I had never facilitated their knowing?

Within the budget restrictions of our rural school, the opportunity to travel to an urban centre is rare. Certainly, we have Internet access; however, the reading level of many global education websites makes them inaccessible to many of our young students. Therefore, I have now learned to encourage my students to explore the world through conversation with classroom guests, reasoned discussion and debate within the school community, and critical engagement with media and children's literature - a process supported by the Ontario Ministry of Education Expert Panel Report on Literacy (Ontario Ministry of Education, 2004), which highlights the importance of critical literacy to focus on issues of "fairness, equity and social justice" (p. 9). In addition, as a teacher in a Catholic school, I refer students to the guidelines of the Ontario Catholic School Graduate Expectations (Institute for Catholic Education, 1998), which call every Catholic student to become a global citizen who:

- $\quad$ respects the faith traditions, world religions and the life-journeys of all people of good will, (p. 6)

- acts morally,

- witnesses Catholic social teaching by promoting equality, democracy, and solidarity for a just, peaceful and compassionate society,

- $\quad$ respects and affirms the diversity and interdependence of the world's peoples and cultures, [and]

- $\quad$ respects and understands the history, cultural heritage, and pluralism of today's contemporary society (p. 9).

Through the integration of rich talk initiatives which facilitate the understanding of global issues, awareness of the responsibilities of global citizenship (such as those detailed in the Catholic Graduate Expectations, Institute for Catholic Education) and a focus on cross-curricular critical literacy programmes, educators have the opportunity to teach social justice and equity issues to all students - including those who live in a social milieu that may shelter them from the daily reality of the issues. After all, if these students are not part of the solution, they become part of the problem.

\section{What Empowerment Looks Like in the Classroom}

As educators, we must accept responsibility for the power that we wield to effect societal change or uphold the status quo. Giroux (1999) challenges teachers to make schools into places of "critical education in the service of creating a public sphere of citizens who are able to exercise power over their own lives and especially over the conditions of knowledge 
acquisition" (p.41). He further exhorts teachers to organize "around the practice of empowerment for the vast majority of students in this country who need to be educated in the spirit of a critical democracy" (p.41).

Effective facilitation by a skilled and enlightened educator is required to ensure that classroom dialogue reaches deeper than the put a penny in the plate mentality. As Mohanty (cited in Brown \& Strega, 2005) reasons, the mere recognition of cultural diversity does little but create "sentimental charity" (p. 138). However, as educators of global citizens, it is incumbent on us to reflect critically on our own stance. While the implementation of global citizenship education practices in the classroom aims to develop a new and deeper understanding of the world for students, the practice also seems to require the development of a new understanding for teachers who are willing to accept that evolving power relations in the classroom must be "relative, productive and negotiated" (Morgan, 1997, p.15) in order to facilitate the implementation of democratic citizenship education. A teacher who facilitates the empowerment of students is willing to concede that his/her knowledge may not be "most worthy" and that there are, indeed, alternate ways of knowing. In an empowered classroom, students know that their choices and their actions have an impact on their societal environment. They are encouraged to think critically about text and media - a practice that requires engagement and motivation on the part of the student. Engagement and motivation result from the implementation of authentic and purposeful activities (Dudley-Marling \& Searle, 1991; Vasquez, 2004) that provide students with relevant experiences and reflect a student's location and ways of knowing (Gee, 1996; Heath, 1983; Power \& Hubbard, 2002). In my classroom, such authentic and purposeful activities have included the creation of multimedia presentations about equity issues, fundraising campaigns for local and international social justice initiatives, publishing a quarterly news magazine, and engaging in community action projects.

Lindfors (1999) supports the power of inquiry acts to deepen a child's "understanding of her own (and others') humanness" (p. 237) through three basic human urges which are present in inquiry, "to connect with others, to understand the world, [and] to reveal ourselves within it" (p. 237). Empowerment of the child recognizes the value of the child's voice. Gallas (1994) affirms, "I have learned that when each member of the classroom community strives to affirm the importance of all voices, the benefit for every child is much greater" (p. 11). Gee (1996) concurs stating, "Schools ought to allow students to transform and vary their Discourses, based on larger cultural and historical understandings, to create new Discourses, and to imagine better and more socially just ways of being in the world" (p. 190). The findings of my research have convinced me that there is great value in opening up our 
classrooms to improved oral curriculum in order to promote relationship building and the development of respect for others within the classroom and within the community.

\section{Why Rich Talk in the Classroom is Essential}

In reflecting on how to further encourage student empowerment in my classroom, the notion of rich talk has been very useful. Oral communication is the basis for implementing a programme of empowerment in the classroom. Rich talk facilitates the engagement of all participants and allows students to acquire and appreciate alternate discourses. All voices are respected and heard. The opportunity to be heard is, in itself, an empowering experience.

If students are expected to freely express their thinking and ideas, they must feel confident that their contributions will be respected by their teacher and their peers. Research demonstrates that students' confidence to express themselves effectively is increased by their comfort level within the environment in which they are required to speak (Dudley-Marling \& Searle, 1991; Gallas, 1994; Lindfors, 1999; Wells \& Chang, 1988).

In a classroom that practices rich talk:

1. All participants in the conversation speak and listen with respect.

2. A student is never fearful of ridicule or teasing when articulating his/her thoughts.

3. Conversation, discussion, or debate is meaningful, authentic, purposeful, and relevant to the students.

4. Teachers are communicative partners who encourage critical thinking and independent expression, while avoiding judgement or censure (Vetter, 2003).

The role of the teacher is to empower the students toward productive talk and critical thinking, and to facilitate classroom discussions. This is done by discussing and modeling effective communication strategies, explicitly teaching the social expectations of group discussion, and allowing students the freedom to interact - to practice with each other without constant intervention by the teacher who responds to each comment and nominates subsequent speakers. In a rich talk classroom, the teacher becomes a collaborative partner (Wells \& Wells-Chang, 1992) who introduces powerful and thought-provoking text and discussion, welcomes interesting guests, and poses carefully constructed questions to elicit higher level thinking while respecting the rights of all students to contribute to the discussion. When students and teachers share authentic, purposeful, and meaningful talk, 
students have the opportunity to explore and expand their global awareness and critical thinking.

\section{Conclusion}

I do not presume this discussion to be the cornerstone of a prescription for change. The issues of discrimination, inequity, and marginalization are too far-reaching in their social implications for one solution. The implementation of teaching methodologies which facilitate critical literacy and a discourse of empowerment to fight social injustice is not a quick fix. However, until today's students become part of the solution, they will continue to be part of the problem - they will prolong a dominant discourse that works to silence and subjugate a significant portion of our citizens and uphold discriminatory practices.

As I reflect back on the remark made by my student about the number of Asian people on a crowded Toronto street, I can see clearly how the implementation of citizenship education in my classroom would have rewritten that remark. To become global citizens, today's children need to be empowered toward a critical stance through the careful facilitation of citizenship education initiatives. Students need to know and understand the issues, value the diversity of others, and be empowered to stand up against the discourse that attempts to subdue or silence any voice. I believe the integration of meaningful, purposeful, and authentic classroom talk - rich talk - and critical literacy in the classroom is the foundation for effective citizenship education.

Indeed, a classroom that encourages opportunity for engagement in societal issues and welcomes the diverse discourses of the classroom, even in the primary grades, takes a major step toward creating an equal platform from which all students can expand their critical literacy skills, broaden their thinking on issues of social consequence, and inaugurate actions that demonstrate pro-active global citizenship.

\section{References}

Brown, L., \& Strega, S. (Eds.). (2005). Research as resistance: Critical, indigenous and anti-oppressive approaches (1st ed.). Toronto, Ontario, Canada: Canadian Scholars' Press.

Darling-Hammond, L. (2002). Learning to teach for social justice. In L. DarlingHammond, J. French, \& S. P. Garcia-Lopez (Eds.), Learning to teach for social justice. New York: Teachers College Press.

Dudley-Marling, C., \& Searle, D. (1991). When students have time to talk: Creating contexts for learning language. Portsmouth, NH: Heinemann.

Gallas, K. (1994). The languages of learning: How children talk, write, dance, draw, and sing their understanding of the world. New York: Teachers College Press. 
D. Vetter

Gee, J. P. (1996). Social linguistics and literacies: Ideology in discourses (2nd ed.). New York: RoutledgeFalmer.

Giroux, H. (1999). Teachers, public life and curriculum reform. In A. C. Ornstein \& L. S. Behar-Horenstein (Eds.), Contemporary issues in curriculum ( $2^{\text {nd }}$ ed, pp. 3643). Needham Heights, MA: Allyn and Bacon.

Heath, S. B. (1983). Ways with words: Language, life and work in communities and classrooms. Cambridge: Cambridge University Press.

Institute for Catholic Education (1998). Ontario Catholic school graduate expectations. Retrieved October 6, 2007, from http://www.occb.on.ca/ice/online_docs/ Graduate\%20Expectations.pdf

Lindfors, J. W. (1999). Children's inquiry: Using language to make sense of the world. New York: Teachers College Press.

Morgan, W. (1997). Critical literacy in the classroom: The art of the possible. New York: Routledge.

Moss, J. (1989). One small voice. Brooklyn, NY: Festival Attractions Inc.

Ontario Ministry of Education. (2004). Literacy for learning: The report of the expert panel on literacy on grades 4 to 6 in Ontario. Toronto, Ontario, Canada: Queens Printer.

Power, B. M., \& Hubbard, R. (Eds.). (2002). Language development: A reader for teachers. Upper Saddle River, NJ: Merrill Prentice Hall.

Statistics Canada. (2005). 2002, 2001 community profiles. Retrieved January 14, 2006, from http://www12.statcan.ca/english/profil01/CP01/Details/Page.cfm?Lang=E

Vasquez, V. M. (2004). Negotiating critical literacies with young children. Mahwah, NJ: L. Erlbaum Associates.

Vetter, D. (2003). Rich talk: An ethnographic study of how grade one students respond and react to current best practice oral communication teaching methodologies. Unpublished master's thesis, York University, Toronto, Canada.

Wells, C. G., \& Chang-Wells, G. L. (1992). Constructing knowledge together: Classrooms as centers of inquiry and literacy. Portsmouth, NH: Heineman.

Wells, G., Chang, G. L. (1988). The literate potential of collaborative talk. In M. MacClure, T. Phillips, \& A. Wilkinson (Eds.), Oracy matters: The development of talking and listening in education (pp. 95-109). Berkshire, England: Open University Press. 